\title{
International Insurance Transactions and the Balance of Payments
}

\author{
by Gerard M. Dickinson *
}

\section{Introduction}

The aim of the paper is to analyse the international economic transactions of the insurance sector in the context of the balance of payments. Particular emphasis will be placed on accounting and valuation issues that arise in seeking to measure the impact of insurance transactions within the flow framework on which balance of payments accounts are based. Since information in the balance of payments is important not only for domestic but also for international economic and monetary decisions, it is essential that there is consistency in the definition of flows and accuracy in measurement. A close look at the conceptual and valuation problems arising from measuring international insurance in the balance of payments is a necessary prerequisite to any attempt to quantify the size of these flows.

Any research on international insurance and the balance of payments must make reference to the work of S. J. Lengyel in his book "International Insurance Transactions: Insurance in the Balances of Payments", 1953. Drawing inspiration from the more general analysis of J. E. Meade, Lengyel produced useful insights into the measurement issues relating to insurance transactions within the balance of payments and made some attempt to measure the extent of the size of international insurance transactions for a number of countries: his efforts to measure flows were frustrated by inconsistencies in definition and inadequate disaggregation of available data. Most of the work of Lengyel was directed at current account transactions and insufficient attention was paid to the various ways that insurance transactions impinge on the capital account of the balance of payments.

We shall also look at the different concepts of surplus/deficits in respect of international transactions of the insurance sector. In common with the balance of payments as a whole, there is no unique definition of what constitutes a deficit/surplus position : there are a variety of definitions depending on the purpose of the analysis. While we shall place a special emphasis on accounting issues, which are in an economic sense ex post, some discussion of policy issues relating to the balance of payments is called for. One such issue relates to policies aimed at achieving a target balance, for a given set of transactions, in respect of one sector of the economy, such as insurance. While such a policy aim may be defensible in respect of the economy as a whole, the pursuit of such a policy at the sectoral level may well lead to a sub-optimal economic policy overall.

\footnotetext{
* Senior Lecturer in Finance and Insurance. The City University Business School, London.
} 


\section{The nature of international transaction In the insurance sector}

Before looking at the international transactions of the insurance sector in the context of the balance of payments, it will be useful, first of all to outline the various ways that these transactions arise. It should be appreciated that the insurance sector embraces not only insurance and reinsurance companies but also brokers, agents and loss adjusters who provide support services. Captive insurance companies set up by multinational firms also constitute a part of the insurance sector and give rise to international transactions, since many of these captives are situated outside the country of the parent organisation and often service the world-wide insurance needs of the group.

We shall outline these various international transactions under three headings :

(a) transactions arising from the provision of insurance services on a trade basis;

(b) transactions arising from the provision of insurance services through overseas establishments ;

(c) transactions unrelated to the provision of international insurance services.

\section{(a) Transactions arising from the provision of insurance services on a trade basis}

The provision of insurance services by an insurer in one country to consumers in another constitutes the most obvious type of insurance trade. Within the EEC insurance parlance, the expression "services business" is employed to represent what we refer to in this paper as "insurance trade". In insurance, in contrast to many other industries, the provision of the service carries with it a countervailing transaction representing an obligation to pay claims. In addition, the provision of services by brokers, agents and loss adjusters will often need to be allowed for either as separate transactions or as specific adjustments to the primary transaction between the insurer and customer. It should be emphasised that it is the provision of the service which represents the primary transaction; payment for the service is best considered as a separate transaction, reflecting the two-sided character of the economic exchange.

Consumer/insurer transactions on a trade basis comprise mainly transactions between insurance companies and corporate buyers of insurance of insurances arranged in respect of the transportation of goods between countries. Virtually all of these transactions represent property and liability insurance services: available evidence suggests that only a negligible amount of life insurance is conducted across national boundaries. The transactions between a captive insurance company located abroad with its parent organisation and subsidiaries in other territories also form a part of insurance trade.

Reinsurance transactions between insurance companies represent a major source of insurance trade. The bulk of these reinsurance transactions are arranged in the form of treaties between companies and it is common for these treaties to be arranged on a reciprocal or 'swap' basis. When such reciprocal treaties exist, there is automatically a corresponding set of transactions which arises from the exchange. Reciprocity of reinsurance treaties may not be symmetrical from a trade point of view. It can happen that one of the parties to the treaty chooses, or is required by legislation, to receive the incoming business through a local branch or subsidiary. 


\section{(b) Transactions arising from the provision of insurance services through overseas establishments}

In recent years, most direct insurance supply by foreign insurers has been carried out through a local branch or subsidiary rather than on a trade basis. One reason for this is that it is difficult to service and attract business in any volume without a significant local presence in a market. In other cases, governments, either directly or indirectly through fiscal or other means, have encouraged the establishment of a branch or subsidiary or discouraged supply on a trade basis. While there are legal and capital differences between a branch and a subsidiary, from an international operations view-point there is not a great difference between these two corporate forms and so in the ensuing discussion we will treat them as being the same. In respect of the provision of insurance through a local establishment, a fundamental question arises as to whether one considers transactions between these organisations and local consumers and local insurers as being international or whether one considers transactions between these organisations and their overseas parent companies as being international. It would seem more appropriate to consider the latter as representing international transactions, since a branch or subsidiary of a foreign company forms an integral part of the local market and from a resource utilisation standpoint is more like an indigenous insurer than its parent company. As a consequence, only transactions between the branch or subsidiary and its overseas parent will be subject to analysis : insurance transactions with other residents in the country of the parent company are likely to be negligible. Intra-group transactions include the provision of administrative and managerial services, and reinsurance transfers, in addition to capital and profit flows. One type of capital transaction which is somewhat peculiar to insurance and reinsurance and which arises from the industry's essentially financial character is the transfer of financial assets already held by a parent organisation to its overseas affiliate company to enable it to strengthen its solvency margins in the event of rapid growth.

International transactions of the insurance sector also embrace mergers and takeovers across national boundaries. Such capital transactions represent a change in the ownership of claims to earnings and to net worth of an enterprise. It is worth observing that it has been the general practice for insurance takeovers in recent years, especially in Europe, to be financed by exchange of shares or overseas borrowing rather than by cash payments through foreign exchange markets.

\section{(c) Transactions unrelated to the provision of insurance services}

There are a number of transactions which the insurance sector is responsible for which are not directly related to its primary productive activity. As in other industries, insurance companies have over the post-war period diversified their operations to include other spheres of activity, often in the financial services sector. In addition, many insurance companies invest a small part of their central free reserves in overseas financial assets. These are portfolio as opposed to direct investment decisions, since they represent investments where there are no managerial ties and where no effective control exists. Such decisions form part of a general policy to gain more effective portfolio diversification and secure higher yields expected to exist abroad. These overseas investment decisions are not entirely independent of the provision of insurance abroad in that they impart greater stability to central capital and thus permit a more aggressive and 
outward-looking underwriting strategy. Transactions not directly related to the provision of insurance services across national frontiers will not, however, be covered in the paper.

\section{International insurance transactions in the balance of payments}

\section{(a) Introduction}

It must be appreciated that the balance of payments forms part of a wider system of social and national income accounts which seek to measure the economic activity within a country and between that country and the rest of the world. The framework and concepts that characterise balance of payments are derivative of these broader systems of accounts and are designed to relate them. Limitations, especially in regard to valuation of flows, in the balance of payments can be traced in the main to limitations in the national income accounting approach. It has been argued elsewhere with some force that economic transactions within an economy and between economies should also be viewed within a value-added context.

Primary emphasis within national income accounting is on the economic flows over a given time period, with little regard being given to the overall stock of foreign assets and liabilities. In the balance of payments, therefore, while changes in the foreign asset and liability position of one country vis à vis the rest of the world are recorded, information rarely exists on the overall size of the stocks of these assets and liabilities : such additional information is clearly important in the formulation of international economic decisions. One might take a direct analogy from management of a business enterprise. To monitor the activity and measure performance, balance sheets are just as important as sources of information as income and expenditure flow statements.

Nevertheless, within this flow framework it must be observed that the conceptual basis on which balance of payments accounts are based, in common with national income accounts generally, have improved significantly over the post-war period and so has the quality of information contained in them. Prior to the early 1950's balance of payments accounts, even in leading industrial nations, sought simply to provide a summary statement of the actual cash payments made within a given time period arising out of economic transactions with the rest of the world and, in some instances, information was restricted to merely the cash payments arranged through foreign exchange markets. A greater concern by national governments in having better information to help them in the formulation of economic policy has been a major impetus in improving the conceptual basis and quality of information of balance of payments accounts. But perhaps the major determinant of this improvement has been the emphasis and work that has been carried out by post-war international agencies, in particular the International Monetary Fund, in demanding more detailed information from member countries in order to fulfil their own monitoring responsibilities. Under an international monetary system, with fixed or floating rates of exchange, accurate information on whether a country is running a persistent trade surplus or deficit is essential to ensure that the rules of the game are being observed. The requirement that members of the IMF should submit balance of payments accounts to that body on a consistent basis has resulted in the IMF itself undertaking research to clarify some of the conceptual and measurement problems associated with the compilation of balance of payment statistics. 
Let us now turn our attention to how international transactions of the insurance sector arise within the context of the balance of payments.

The balance of payments accounts for a given country comprise two sets of transactions : those arising from the exchange of economic values between non-residents with the resident insurance sector and those between residents and the non-resident insurance sector. In the discussion we shall tend to look at the various transactions that arise as a result of the provision of international insurance services from the standpoint of the resident insurance sector, and the reader is asked to keep in mind that there will always be a corresponding and opposite set of transactions in respect of the activities of the non-resident insurance sector with residents.

It should be noted that we will seek here to assess how these international insurance transactions fit into the balance of payments format and how they should be valued in the light of prevailing national income accounting practices. The actual recording of transactions by individual countries differs in varying degrees from this norm because of : $(a)$ a failure to understand the nature of international insurance transactions and $(b)$ available sources of data not permitting a more detailed compilation.

At the same time, the valuation of insurance transactions in the balance of payments does not mean that this is the only mode of valuation. Indeed, as we shall note later, alternative valuation criteria would appear preferable in some areas in measuring the real flows of resources embodied in the provision of insurance services and claims on real resources arising from changes in international indebtedness.

\section{(b) Insurance trade and the balance of payments}

It will be recalled from the earlier discussion that insurance trade comprises direct insurance services between insurers and consumers and reinsurance exchanges. Reinsurance transactions between a parent organisation and its overseas branches and subsidiaries will be included as a part of these reinsurance transactions; all other intra-group flows across national frontiers will be considered within the context of transactions arising from overseas operations.

It should be stressed that whether an international insurance transactions is considered to take place or not depends on the residency of the parties to the exchange, it does not depend on the location of the property, liability or life that is covered. It will, however, be clear that the location of the insured risk will affect the pattern and size of flows. For example, policies of some multi-national firms to arrange and pay for their world-wide insurance requirements centrally may well influence the pattern of claim flows, since claim settlements arising from arranging insurance cover abroad may be made directly to the overseas organisation where the loss occurs rather than to the parent organisation.

When insurances are arranged between residents and local agents of non-resident insurers, it would seem appropriate to view the transaction as if it had been arranged directly with the non-resident insurer, as the agent is acting directly on behalf of the non-resident insurer. Commission payments from non-resident insurers to local agents for acquiring and servicing local business will themselves constitute international transactions. In regard to local agencies of foreign insurers, sometimes the agency is from 
an operational standpoint tantamount to being a branch organisation, with powers over pricing, underwriting and settlement of claims. Nevertheless since it would be difficult to establish an appropriate set of criteria for distinguishing between agencies with different degrees of responsibility and control, it would seem preferable to treat all business carried out through local agencies as trade transactions. In contrast, brokers are independent of insurance companies and have a clear intermediary role and so transactions between local consumers and foreign insurers arranged by brokers are clearly of a trade character. All insurance supply by Lloyds of London is therefore of a trade character.

In identifying and analysing how transactions emanating from insurance trade arise within the balance of payments, it will be convenient if the discussion is carried out under the following headings :

i) non-merchandise insurance ;

ii) merchandise insurance;

iii) life insurance and contractual pensions.

By discussing the various types of insurance under these three headings, we will be conforming to classifications adopted by many countries in compiling their balance of payments statistics.

\section{(i) Non-merchandise insurance}

Non-merchandise insurance is normally defined to cover all classes of insurance and reinsurance, excluding insurance on the international shipment of goods. The service element in life insurance policies is usually embraced within this broad classification.

In common with all transactions in the balance of payments both aspects of the economic exchange are recorded. It will be useful for expository purposes to consider one aspect of the economic exchange as an 'initiating' transaction and the other as a 'financing' transaction. In respect of insurance trade, the 'initiating' flow is the provision of service and how the service is paid for during the period of measurement is the corresponding 'financing' flow. The countervailing claim flow can be thought of as the import content of the primary export service, although in constrast to trade in goods, the import content in insurance arises subsequent to the export rather than in advance. The provision of a net insurance service (i.e. net of claims) results in a transfer of resources from the exporting country - skilled labour, risk capital, entrepreneurial skills and product technology.

Let us now turn to the valuation of these flows. Following current national income accounting practices, an insurance service is deemed to be provided when the agreement is made and the premium becomes payable, and in respect of claims when the insurance company admits a liability for payment. It will be readily apparent that the provision of an insurance service will not necessarily be co-terminous with the time when an actual payment is made.

The value placed on the provision of an insurance service should be the market value for such a service at the time of valuation. Intra-group transactions may be recorded at higher or lower than what the corresponding market value of such services 
and if this is so, valuation adjustments are called for. This might apply to group reinsurance transactions, but it is more likely to apply in respect of payments by industrial corporations to their overseas captive insurance companies. If adjustments to the actual recorded values from intra-group transactions require adjustment, the difference between the premiums paid and these imputed market values will need to be compensated for in the capital account in the form of change in international indebtedness. For example, if the parent organisation of a multi-national firm makes premium payments to its captive insurance company abroad in excess of what might be considered to be the market level, the difference should be viewed as a capital outflow. A more general issue relating to the valuation of insurance trade arises from the fact that $(a)$ an insurance service is provided over a period of time, normally a year, and $(b)$ there is a lag in reporting and settlement of claims. Since the balance of payments seeks to measure transactions over a discrete period of time, this introduces measurement problems. If one were to appeal to business accounting principles it would seem appropriate to value net insurance trade as premiums earned less claims incurred; that is, adjusting for the pre-payment of premiums and for the time lags in reporting and settlement of claims. Indeed, Lengyel in his earlier work on insurance and the balance of payments argues that insurance transactions should be recorded in this way, basing his argument on symmetry with business accounting practice. Business accounting principles are not, however, the appropriate criteria for deciding on how international economic transactions should be assessed. Nevertheless, even from the wider economic standpoint, a valuation based on premiums earned less claims incurred is a reasonable measure of the value of the real resources embodied in the service provided during the period of measurement. But the structure of the balance of payments is designed to be consistent with the existing national income accounts, despite their limitations. As a result the valuation of international insurance transactions in practice reflects the treatment of insurance transactions generally in national income accounts. This means that net insurance exports are usually recorded on the basis of premiums receivable less claims payable during the period of account and with no attempt to adopt an accrual approach in apportioning these flows to a given period. National income accounting in many countries places a greater measurement emphasis on income and expenditure flows rather than on the measurement of output, even though in the aggregate they are constrained to be equal.

The corresponding 'financing' flows associated with the provision of insurance services across national boundaries are recorded in the capital account. Payments for insurance or reinsurance result in changes in net foreign currencies holdings or changes in the stock of foreign assets and liabilities. Indeed 'financing' flows associated with the provision of insurance services have in recent years resulted increasingly in changes in indebtedness in many countries. This has been attributable in part to a greater preference on the part of international insurers and reinsurers for currency matching of expected claims outflows in a regime of floating exchange rates, and in part to government policies requiring premium balances arising from insurance trade to be held in the country in which they are generated, either in the interests of consumer protection or as a result of general exchange control regulations.

These 'financing' flows arise in various ways and are recorded in different parts of the capital account. When payments arising from the export of insurance services are held in foreign securities, either in 'trust' or in central funds, this results in an 
increase in foreign portfolio investment : if public securities are bought as opposed to private sector securities these will normally be classified separately in the capital account. In respect of international reinsurance transactions, when funds arising from the provision of reinsurers cover are held by the ceding foreign reinsurer, e.g. under ' gross reserving' requirements, funds locked up in this way, represent an increase in corporate lending to foreigners.

We noted earlier that in order to conform with national income accounting, the value of insurance services is often recorded in the balance of payments on a receivable' and 'payable' basis. To the extent that these values differ from the actual premiums received and claims paid within the accounting period, the difference needs to be adjusted for in the capital account. For example, if insurance export premiums receivable less claims payable are less than premiums paid less claims paid, the difference will represent an increase in the foreign liabilities of the country in question.

Some attempt is made by governments in compiling balance of payments accounts to seek to classify capital transactions into long-term and short-term in the interests of monitoring capital movements. It would seem preferable to classify all capital transactions associated with insurance trade as long term, even though some of the financial assets held may include investments with a maturity of less than one year. This is because these investments are held, even when they are held voluntarily, to cover the operating risks of the business and in general would not be switched into another currency except if the volume of business transacted were to fall sharply or if the company were to stop writing business altogether. It is possible that some of these foreign assets may be deployed as a part of a general mobilisation of capital by a multi-national insurer or reinsurer to meet an exceptionally large level of claims elsewhere in the world. But since the cause of such a movement of capital would be independent of expectations of a monetary nature (e.g. changes in exchange rates or interest rates) this would not seem to challenge the appropriateness of classifying all capital transactions associated with insurance trade as being of a long-term character.

Income from these holdings of overseas investments generated from insurance trade give rise to another set of transactions in the balance of payments. Investment income and realised capital gains (less local taxes and transactions costs) are a part of factor income payable to residents and are recorded in the current account. To the extent that this income is reinvested in additional holdings of foreign investments or additional claims on foreign reinsurers, there will be corresponding increase in foreign asset holdings in the capital account.

Payments to resident agents, brokers and adjusters, by non-resident insurers for their services are also factor income and are recorded in the current account.

\section{(ii) Merchandise insurance}

Merchandise insurance is recorded by many countries as a separate item in the balance of payments and relates to the provision of transportation insurances, excluding reinsurance, on the international shipments of goods. It consists of $i$ ) insurances on goods in transit to and from the country in question, and ii) insurances on goods in transit between third-countries. From a valuation stand-point, transportation insurances on goods being carried between third-countries are similar to other forms of non-life 
insurance recorded in non-merchandise insurance. In respect of insurances on imports and exports of goods in the country in question, particular valuation problems arise. These emanate from two issues, $i$ ) from the fact that the purchase of insurance on goods in transit is not always made by owners and ii) the valuations of goods on uniform bases in the balance of payments, i.e. f.o.b. or c.i.f., do not necessarily correspond to the time when the ownership of the goods traded changes.

If the purchase of insurance always corresponded to ownership then the value of insurance exports for a country would be the purchases of insurance by non-residents with the resident insurance sector. But in some instances, insurances may be arranged and paid for by the exporter after the change of ownership to the importer takes place. In such circumstances, the exporter is in essence acting in an agency capacity for the foreign importer and if such insurance is arranged with an insurance company in the exporting country, then this should be imputed as a transaction between the foreign importer and insurance company and thus recorded as an insurance export. Correspondingly, an exporter may arrange cover for the foreign importer with an insurance company abroad subsequent to the change in ownership of the goods and so this should not be treated as an insurance import.

The main valuation problem, however, that arises in respect of merchandise insurance transactions stems from the use of uniform bases for valuing exports and imports of goods. In the main, countries in their balance of payments either value both exports and imports in an f.o.b. basis or exports f.o.b. and import c.i.f. Indeed the separate recording of merchandise insurance, along with freight transactions in the balance of payments, is designed to provide a consistent valuation basis with the traded goods to which they relate. The net effect of recording transportation insurance in this way is that insurance transactions are recorded in the balance of payments as if ownership of goods changes at the point of valuation : namely in respect of f.o.b. valuations at the port/frontier of the exporting country and in respect of c.i.f. at the port/frontier of the importing country. Thus if goods exported are valued on a f.o.b. basis and goods imported on a c.i.f. basis, all goods in transit are deemed to be owned by non-residents and so all insurances arranged on such goods, whether by non-residents or residents, with residence insurance companies are deemed to be insurance exports ; correspondingly, none of the insurance arranged by residents with non-resident insurers is considered to represent insurance imports. There is as a result a clear overstatement of the recorded value of insurance exports and a understatement of insurance imports in balance of payments accounts. The countervailing claims flows are valued in a way consistent with these premium flows and this tends to reduce to some extent the bias in measurement. Similarly, when both exports and imports of goods are valued on a f.o.b. basis, there may be a lack of correspondence between recorded insurance trade in respect of transportation insurance and that which would be considered to have taken place on a change of ownership basis.

In common with non-merchandise insurance, there will be a corresponding set of financial transactions in the capital account representing changes in foreign currency holdings or changes in international indebtedness. It will be clear that since some insurance trade will be embodied in goods traded, these 'financing' flows may not be easily separable from the 'financing' flows associated with the goods to which they relate. 


\section{Life insurance}

On account of its savings character, the purchase of life insurance across national frontiers entails a capital flow as well as a payment for a service. In measuring the capital component, the flow approach adopted under existing national income accounting practices is usually employed rather than an actuarial apportionment. The capital flow component is therefore calculated as a residual of the cash flows into the life fund over the period of measurement, excluding investment income. A sum equivalent to the expenses sustained by the resident insurance company during the period of measurement is deemed to represent the value of the service export. This service element is classified in the balance of payments of most countries as a part of "nonmerchandise" insurance (see page 22). Given the cash flow emphasis in national income accounting, actuarial valuation increases in the equity of non-resident policyholders in the life funds of resident insurance companies, other than those arising from investment income and these net cash additions, are not recorded. Investment income less local taxes accruing on this share of life funds is treated as a separate transaction analogous to interest payments on portfolio investment.

In the interest of exposition it will be useful if the various transactions that arise from international insurance trade are portrayed within the format of the balance of payments. This is done in Table 1 . In view of the detailed character of official balance of payments accounts, only a summary version will be used, with transactions classified under the two broad headings: current account and capital account. The current account embraces trade flows in goods and services, including payments on foreign assets. Transactions in the capital account are divided into those within the nonmonetary sector and those in the monetary sector. Non-monetary sector transactions cover investment and lending of the private sector and that of government not directly related to monetary management; monetary sector transactions relate to official financing and for simplicity are classified as changes in gold and currency holdings, and other financing.

The balance of payments, as we noted earlier, is based on a double entry system and so both sides of the economic exchange are recorded, once as a credit and once as a debit. Exports, decreases in foreign assets and increases in foreign liabilities are recorded as credits; imports, increases in foreign assets and decreases in foreign liabilities are recorded as debits.

Since the balance of payments of a particular country embraces both transactions arising from the import and export of insurance services, to simplify exposition Table 1 details only transactions that can arise from service exports by the resident insurance sector. A parallel and opposite set of transactions will exist in respect of the import of insurance services.

\section{(c) Overseas insurance establishments and the balance of payments}

As we noted earlier, overseas branches and subsidiaries are considered to be residents of the country in which they are located and so insurance services provided to local consumers do not enter into the balance of payments. Thus only transactions between these overseas organisations and their parent companies and with consumers outside the country in which they are located are deemed to be international. From the standpoint of the balance of payments of the country of the parent organisation, 


\section{Table 1}

Transactions arising from insurance trade in the balance of payments

Current Account

1. Trade in goods

(merchandise)

2. Freight and insurance on international shipments of goods

3. Investment income

(a) On direct investment

(b) On portfolio and other investment

\section{CREDIT}

Export of merchandise insurance (net premiums)

Interest on foreign assets (less overseas taxes payable)

Interest on balances held with non-resident reinsurers (less overseas taxes payable)

Exports of nonmerchandise insurance (net premiums)

Services provided by resident brokers and adjusters

\section{DEBIT}

Claim payments on merchandise insurance exports

Net interest accruing to non-residents on life policies with resident insurance companies

Claims payments on non merchandise insurance Services provided by non-resident agents/ brokers and adjusters

Net increase in foreign

Increase in equity of non-residents in resident life insurance company funds private sector investments Net increase in funds held by non-resident reinsurers

Net increase in foreign government securities

\section{Monetary sector}

9. Other official financing

10. Changes in gold and currency holdings

decrease ${ }^{*}$ in foreign currency holdings
Increase in foreign currency holdings

* decrease arising from exceptionally large claim payments 
these international transactions are largely confined to intra-group flows, While overseas organisations can supply insurance needs of residents in the country of their parent organisation, such instances are rare since these needs would normally be handled by the parent organisation itself.

\section{Investment and earnings flows}

Investment decisions to set up or expand overseas branches or subsidiaries constitute important capital flows. Again, from the standpoint of the balance of payments of the country of the parent organisation, such decisions represent increases in foreign direct investment. The 'financing' transactions associated with these direct investment decisions take various forms. If payment is made via foreign exchange markets, this will result in a decrease in net foreign currency holdings. On the other hand, if payment is made by virtue of overseas loans arranged by the parent company then the corresponding flow will be an inward portfolio investment. Sometimes expansion of an overseas operation is financed through foreign loans being raised by the overseas branches or subsidiaries themselves; in such cases neither the investment decision nor the raising of the loan features in the balance of payments, as they do not constitute international transactions. Indeed, it is because of the neutral effect that such financing has on the balance of payments that insurance companies in some countries have been encouraged by their governments to adopt this form of financing, if they wish to expand their overseas operations. When demand for capital is for the purpose of strengthening local solvency margins, direct investment abroad by an insurance company can also take the form of a transfer of existing securities to the overseas organisation.

Mergers and takeovers of insurance companies across national boundaries are a special case of foreign direct investment. The acquisition of the shares of the foreign insurer by the resident insurance company represents an increase in the foreign direct investment, with the associated 'financing' flows again taking various forms. Nevertheless, it has been increasingly popular in recent years for mergers and takeovers to be financed through an exchange of shares, and in such circumstances the 'financing flow' is represented in the balance of payments as inward direct investment.

Since earnings of overseas branches and subsidiaries (less local taxes payable) represent factor income to their parent organisations they give rise to a separate transaction in the current account. This applies whether they are remitted or not. When an overseas affiliate is a jointly-owned subsidiary, net earnings should be allocated in proportion to the degree of ownership. In valuing earnings, upward adjustment will need to be made if reported earnings are understated on account of conservative solvency valuation criteria. In the balance of payments, in common with national income accounts, no allowance is made for valuation changes and so in calculating profits, unrealised capital gains or losses should be excluded. To the extent that these overseas profits are ploughed back in the overseas affiliates producing them, this will give rise to an increase in foreign direct investment.

\section{Intra-group services}

The provision of managerial and other services by a parent company to its overseas branches and subsidiaries constitutes an export as far as the balance of 
Table 2

Transactions arising from overseas establishments

in the balance of payments

Current Account

1. Trade in goods

(merchandise)

2. Freight and insurance on international shipments of goods

3. Investment income

(a) On direct investment

Earnings of overseas

branches and subsidiaries

(less overseas taxes

payable)

(b) On portfolio and other investment

4. Government services and transfer payments

5. Other services

Capital Account

Non-monetary sector

6. Private long-term capital flows

(a) Direct investment

(b) Portfolio and other investment
Management services provided by parent company for overseas branches and subsidiaries

Management services provided by overseas branches and subsidiaries for parent company

\author{
Transfer of shares to \\ foreign acquiring company \\ Transfer of financial assets \\ to overseas branches and \\ subsidiaries \\ Foreign loans raised by \\ parent company for \\ overseas branches and \\ subsidiaries
}

Receipt of shares in foreign acquired company

Increase in equity in overseas branches and subsidiaries

7. Private short term capital flows

8. Local and Central government

Monetary sector

9. Other official financing

10. Changes in gold and Decrease in foreign currency holdings currency holdings
Increase in foreign currency holdings 
payments of the country of the parent company is concerned. In the same way, services provided by the overseas organisations for the parent companies are imports. When the provision of such services does not lead to a cash remittance, there will be change in indebtedness in the capital account. In respect of services provided by the parent company, this will result in an increase in the equity in the overseas organisation and when provided for the parent company as a decrease.

Large firms of brokers and adjusters which service insurance abroad have in the same way as insurance companies found it necessary to establish a local presence in order to service their business. When such overseas organisations exist, they can give rise to intragroup service transactions similar to those by international insurers.

The above discussion give a detailed picture of how insurance transactions are recorded in the balance of payments, using as a guide the practice adopted in Europe and North America. Not all countries record transactions in this way : sometimes they vary on account of differences in national income accounting approaches and sometimes because of differences in the data available for compilation. For a number of transactions especially those in the capital accounts, it is often difficult to judge whether information is collected or valued appropriately, since they are subsumed within broader classifications without adequate annotation.

\section{Deficit/Surplus on Insurance transactions in the balance of payments}

We shall now address ourselves to the question of how information in the balance of payments can be summarised to ascertain whether a country has a surplus or deficit in respect of these international insurance transactions. Since each transaction within the balance of payments is recorded twice, once as a credit and once as a debit, insurance sector transactions across all current and capital account categories will necessarily sum to zero, apart from measurement errors. A deficit or surplus, therefore, can only arise in respect of transactions falling within a subset of categories. While various subsets of categories can be postulated, we could suggest that the following are the most useful from the viewpoint of economic analysis : (a) balance on trade in insurance services; (b) balance on overall insurance services; (c) balance on transactions requiring official financing.

In measuring the value of transactions of the resident insurance sector with nonresidents and that of the non-resident sector with residents, it would seem appropriate to depart from the valuation criteria adopted within the balance of payments in certain respects. More specifically, emphasis will be placed on measuring the value of the real resources embodied in the provision of service rather than on measuring income and expenditure flows.

\section{Balance on trade in insurance services}

Whether a country is a net exporter or importer of insurance services is a significant piece of economic information. We suggest that insurance services trade be defined as merchandise and non-merchandise insurance, and services provided by agents, brokers and loss adjusters. On the other hand, it would seem preferable to exclude intra-group management and other costs as a part of trade, since the provision 
of such services does not arise under competitive conditions but to a large extent reflects internal corporate policies.

In seeking to measure whether a surplus or deficit on trade in insurance service exists, adjustments to the information recorded in the balance of payments will be needed. Some adjustments will clearly be required in respect of recorded information for merchandise insurance exports and imports, in view of the biases that arise from the use of uniform bases for valuing trade in goods. When goods are valued at c.i.f. for imports and f.o.b. for exports, the degree of bias can be high. Thus for countries which employ this uniform valuation basis and which have competitive cargo insurance markets, the apparent balance on merchandise insurance trade can be significantly overstated. In such instances, independent information from other sources, mainly industry sources, will have to be obtained if realistic estimates are to be made.

Net premiums earned less claims incurred afford a reasonable measure of the real resource transfer in the provision of an insurance service, so long as estimates of claims liabilities are made on realistic bases. The degree of bias from not adjusting official figures in this way will vary directly with the rate of growth of insurance trade; if the rate of growth is low, the overstatement in using unadjusted figures will be small.

All transactions should be valued at market values, which will require in some instances imputing values, especially for intra-group flows. Consistent with the market valuation principle, transactions should be converted at the prevailing rates of exchange or the average rates of exchange over the period of measurement.

Whether there is a surplus or deficit on trade in insurance services, this is not to be taken alone as a measure of the international competitiveness of the local insurance industry. This is because the provision of international insurance services through overseas branches and subsidiaries is a direct substitute for insurance arranged on a trade basis; indeed since branches and subsidiaries are often set up in order to service an enlarged volume of business more efficiently, it could well reflect the reverse.

\section{Balance on overall insurance services}

This is a broader concept, embracing not only trade in insurance services but also service payment for consumption or utilisation of foreign-owned resources. Earnings (less foreign taxes) of overseas branches and subsidiaries and net investment income on foreign portfolio and other investment represent the major source of these service payments. Intra-group management and other service costs, which represent utilisation of non-resident labour as opposed to capital resources, are also included. Indeed all transactions that the insurance sector gives rise to in the current account of the balance of payments are embraced within this broader concept, i.e. the net transfer of factor and non-factor services across national boundaries on a trade and establishment basis.

In the balance of payments of many countries, it is not uncommon for earnings of branches and subsidiaries to be recorded without adjustment from published sources, often based on returns submitted by insurance companies to the supervising authorities for solvency assessment. Not infrequently, these published sources understate earnings, because of an inherent tendency of solvency valuation criteria to capitalise earnings for a growing volume of business. 
Earnings should be adjusted where possible to realistic bases. For non-life insurance, available sources of data suggest that in some countries earnings may be more easily estimated indirectly by use of the followings identity:

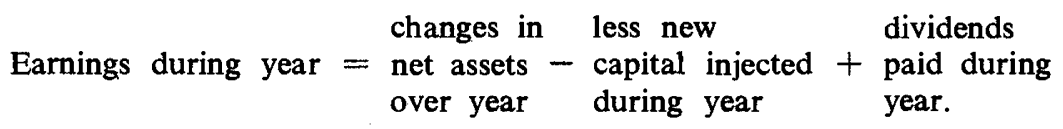

That is by measuring uses rather than sources of earnings.

It is much more difficult in respect of life insurance to estimate realistic earnings or that part of the actuarial surplus that represents earnings attributable to an overseas parent organisation. This is because of the differences in time scale and the tendency of actuarial valuations to simply disclose earnings that are planned for distribution. Unfortunately, published information only permits crude estimates of these earnings figures, but the problem is not so serious as the volume of life insurance conducted by non-resident owned insurers is comparatively in most countries.

\section{Balance requiring official financing}

Finally, it is useful to have a measure of the extent to which international insurance transactions necessitate official financing by the monetary authorities. The degree of official financing will depend : (a) on the balance on overall insurance services and the relative size of the 'initiating' (as opposed to 'financing ') capital transactions and (b) on the relative extent to which financing of transactions is arranged through foreign exchange markets.

In contrast to many other industries, international insurance transactions have been financed to a significant degree in recent years by changes in private sector indebtedness. We discussed earlier the growing preference for currency matching, the impact of solvency and exchange control constraints on the freedom to remit of premium balances and profits and the growing practice of financing expansion and take-overs through overseas borrowing and the exchange of shares. The degree to which international insurance transactions entail official 'financing' will therefore vary with the economic, legislative and insurance market environment in the country concerned in comparison to environments in overseas countries where resident insurance companies compete. It is possible, therefore, for a country to have a surplus on insurance services together with a net inflow of capital (i.e. "initiating") and for a deficit on official financing to exist.

\section{Balance of payments policy and International Insurance transactions}

As a part of general macro-economic policy, governments often seek to achieve a 'target' balance, or at least reduce an existing deficit to some predetermined level, in their balance of payments. Transactions encompassed within these 'target' balances vary from country to country, depending on institutional conditions and the general approach of economic management. But since emphasis tends to be placed either on a current account balance or a monetary balance, i.e. broadly similar to the concept of ' official financing balance' discussed earlier, we shall frame the ensuing discussion within the context of these two concepts. 
At the same time, it is rare for governments to set down specific ' target' balances for individual sectors within the economy. But in practice with the administrative decentralisation of policy in the interests of achieving this aim, the overall 'target' balance is not infrequently translated directly into similar targets at the sectoral level. The issues we shall discuss in this section are (a) the general economic efficacy of seeking to achieve a balance or minimise a deficit for a single sector of the economy, (b) policies that might be introduced if such a sectoral balance for the insurance sector were sought, and $(c)$ the economic effects that might ensue from such policies.

\section{Policies aimed at achieving a sectoral balance on current account transactions}

While to achieve a balance on current account transactions as a whole may represent a sound economic objective, it does not follow that this is so for international transactions at the sectoral level. To seek to achieve a balance on each sector in the economy stands in direct conflict to the principle of some productive specialisation on which the economic rationale for international trade is based. Moreover, the aim of achieving sectoral balances carries with it a corresponding commitment to reduce sectoral surpluses and this might, because of structural interdependences, have further adverse repercussions on overall economic performance.

Turning to insurance, if a sectoral deficit exists in respect of current account transaction over time, this may be due to general economic causes, such as an overvalued currency or inappropriate monetary or fiscal policy, or to the fact that foreign sources of supply are more competitive. We shall not concern ourselves here with the more general economic and monetary adjustment issues but concentrate on the latter. When foreign competition is the cause of a deficit, attempts to achieve a balance are likely to lead to government intervention in the market or to policies aimed at reducing any cost advantage that the foreign insurer or reinsurer may possess. In insurance, judging by past precedents, this intervention might take the form of : (i) prohibiting or discouraging foreign sources of supply through discriminatory fiscal or other means, (ii) requiring foreign companies to supply insurance services on an establishment rather than trade basis, because of the reduced utilisation of foreign owned resources.

Even from the national standpoint, the introduction of such policies, if successful in this context, may give rise to economic consequences which are not consistent with the attainment of other government objectives. In the first place, the question arises whether domestic resources replacing foreign resources would not be more efficiently deployed elsewhere in the economy. Because of differences in industrial structure and protection afforded in other sectors, it is not possible to generalise on whether output and employment would be higher or lower, but it is clear that policies aimed at discouraging relatively more efficient sources of insurance supply will tend to impart an upward pressure on prices, albeit marginal. Moreover, these restrictionist measures may call forth retaliation in respect of the country's own exports, and these may not necessarily be in the insurance sector.

The main economic repercussions from the introduction of such policies are likely, however, to be felt in their impact on the availability and quality of insurance as a factor input in the production of other goods and services in the rest of the economy. Because foreign sources that may be discouraged by these policies are likely 
to be the larger insurers and reinsurers with an extensive insurance service capacity, these repercussions might result in potential economic costs in a variety of ways. A lack of adequate property and liability insurance cover on large, technologically advanced products and processes may lead to delays in their introduction and thus have an adverse affect on growth. A reduction in the quality of loss prevention and risk management advice to corporate consumers may result in higher losses of economic resources and lead to a greater degree of disruption to output and employment than would otherwise be the case. Indeed, an insistence that foreign importers arrange their cargo insurances with domestic insurers in which they have little confidence may itself tend to discourage some exports. These wider effects may be marginal in themselves, but in view of the relative magnitudes involved, may well offset any gains from the pursuit of such policies.

\section{Policies aimed at achieving a sectoral balance on official financing}

Similarly, attempts to achieve a sectoral balance in respect of official financing are likely to be suboptimal. As before this aim may give rise to intervention in the insurance market or in its market environment with the same consequences, but since this balance also embraces capital transactions, exchange controls are more likely to be deployed as an instrument of policy. Exchange controls on capital transactions take various forms, including the 'locking-in' of funds generated from business written by foreign insurers and reinsurers in the country and the imposition of requirements that overseas expansion by domestic insurers be financed by foreign borrowing.

We noted earlier that solvency regulations and insurance company financing and investment policies are such that only a small amount of the net cost of insurance is arranged through foreign exchange markets. As a result foreign exchange savings over time that might accrue from the introduction of greater exchange controls would often yield comparatively little. At the same time, the additional uncertainty that may be caused by their introduction may induce shortages in insurance and reinsurance cover which the market has to acquire from outside, or increase the cost of such cover. Similarly, restrictions on capital remittances to finance insurance operations abroad may result in a loss of earnings from these overseas interests, if foreign borrowing is difficult to arrange.

In developing countries, because of a much higher opportunity cost for foreign exchange, currency savings from such exchange controls may in certain circumstances be optimal from the national standpoint. But even here, given the stochastic nature of claims, some payment in foreign exchange may be a reasonable price to pay to insure against an uncertain outflow of foreign currency which may be needed to finance imports of machinery and equipment from abroad as a result of large, domestically insured losses.

\section{Conclusions}

An attempt has been made in this paper to outline the nature of international insurance transactions and how they arise within the balance of payments. Particular attention has been placed on how these transaction are valued in practice and on the adjustments needed to convert the information contained in the balance of payments to 
provide realistic measures of these international flows. Three concepts for summarising the impact of international insurance transactions on the balance of payments were advanced, with a brief discussion of the dangers of partial analysis implicit in government policies aimed at seeking to eliminate a deficit in respect of insurance transactions.

The paper is in a sense exploratory. An obvious next step would be to attempt to quantify these international flows. In particular, estimates of the three summary measures proposed for a limited number of countries would afford a useful and practical line of enquiry, since it would permit both comparisons between countries and within a country over time. Since the information contained in the balance of payments is restricted to flows, additional information on the stocks of foreign assets and liabilities of the insurance sector would provide a more complete picture.

To attempt to measure these international flows and stocks in individual countries, it is clear that information in the balance of payments will need to be supplemented from a variety of sources, mainly industry sources and company accounts. Even then there will still be gaps in the information and some econometric estimation will also be called for.

\section{SELECTED BIBLIOGRAPHY}

1. CARTER, R. L., and DICKINSON, G. M., "Economic effects of restrictions on international trade in reinsurance", Proceedings of 4 th International R.O.A. Conference, Cambridge, 1977.

2. COOPER, R., The economics of interdependence, McGraw Hill, 1968.

3. DICKINSON, G. M., "Classification of foreign capital flows of insurance companies", Journal of Risk and Insurance, Vol. 38, 1971.

4. LENGYEL, S. J., International insurance transactions : insurance in the balance of payments, Wadley and Ginn, London, 1953.

5. International Monetary Fund, Balance of Payments Manual, Washington, 1961/1970. Balance of Payments Yearbook, Washington, Annual.

6. MEADE, J.E., The Balance of Payments, Oxford University Press, 1951.

7. JOHNSON, H. G., “Towards a general theory of the balance of payments", Readings in International Economics, ed. R. E. Caves and H. G. Johnson, Mc Millan, 1970.

8. United Nations Yearbook on National Accounts Statistics, New York, 1970. 